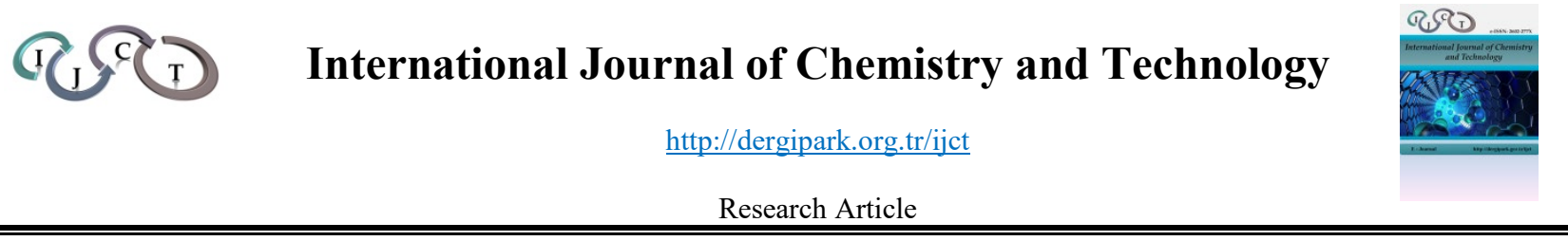

\title{
The activity of ceria supported complex in hydrogen generation
}

\author{
Dilek KILINÇÇ,*, (1) Ömer ŞAHIN ${ }^{2}$ \\ ${ }^{1}$ University of Siirt Faculty of Science and Arts Department of Chemistry, Siirt, Turkey \\ ${ }^{2}$ University of Siirt Faculty of Engineering, Department of Chemical Engineering, Siirt, Turkey
}

Received: 22 June 2020; Revised: 26 April 2021; Accepted: 26 April 2021

*Corresponding author e-mail: dkilinc@siirt.edu.tr

Citation: Kılınç, D. ; Şahin, Ö. Int. J. Chem. Technol. 2021, 5 (1), 26-32.

\begin{abstract}
In this study, we studied the ceria supported $\mathrm{Ni}$ complex preparation and using it as a catalyst in $\mathrm{NaBH}_{4}$ hydrolysis for $\mathrm{H}_{2}$ production. $\mathrm{NaBH}_{4}$ hydrolysis system was studied in different parameters, as concentration of $\mathrm{Ni}$ complex, concentration of $\mathrm{NaBH}_{4}$, concentration of $\mathrm{NaOH}$, amount of catalyst and temperature. Additionally, catalyst was characterized by several analysis methods. Finally, the kinetic calculation of $\mathrm{NaBH}_{4}$ hydrolysis reaction was studied at $20^{\circ} \mathrm{C}$ $50{ }^{\circ} \mathrm{C}$ the activation energy was found to be $27.581 \mathrm{kJmol}^{-1}$. The aim of this study is to emphasize that ceria support can be used to increase the catalyst surface and to obtain the high hydrogen generation activity through hydrolysis of $\mathrm{NaBH}_{4}$. The experimental results show that ceria supported $\mathrm{Ni}$ complex was an effective catalyst in hydrolysis of $\mathrm{NaBH}_{4}$.
\end{abstract}

Keywords: Ni-complex, Sodium borohydride, Hydrogen generation.

\section{INTRODUCTION}

Hydrogen is a renewable energy sources which deliver sufficient energy that was clean and environmentally friendly. ${ }^{1}$ But, two important impediments are present to hydrogen generation and storage for using hydrogen. Due to its $\mathrm{H}_{2}$ evolution at low temperature, great $10.8 \% \mathrm{H}_{2}$ content, delivered non-toxic byproducts and stability in alkaline solutions $\mathrm{NaBH}_{4}$ is commonly used. ${ }^{2}$

$\mathrm{NaBH}_{4}+2 \mathrm{H}_{2} \mathrm{O} \rightarrow 4 \mathrm{H}_{2}+\mathrm{NaBO}_{2}$

The use of heterogeneous catalysts was considered one of the ways to control the hydrolysis of $\mathrm{NaBH}_{4}{ }^{3} \mathrm{NaBH}_{4}$ hydrolysis reaction is controlled by different noble or
Seryum oksit destekli kompleksin hidrojen üretimindeki aktivitesi

ÖZ

$\mathrm{Bu}$ çalışmada, seryum oksit destekli $\mathrm{Ni}$ kompleksinin hazırlanışını ve $\mathrm{NaBH}_{4}$ den hidrojen üretiminde katalizör olarak kullanılışını inceledik. seryum oksit destekli Ni kompleks katalizli $\mathrm{NaBH}_{4}$ hidroliz reaksiyonu; $\mathrm{NaBH}_{4}$ ve $\mathrm{NaOH}$ konsantrasyonuna, sıcaklığa, katalizör miktarına ve katalizör içersindeki Ni kompleksinin konsantrasyonuna bağlı olarak çalışıldı. Ayrıca sentezlenen katalizör farklı analiz yöntemleriyle karakterize edildi. Son olarak da $20{ }^{\circ} \mathrm{C}-50{ }^{\circ} \mathrm{C}$ sıcaklık aralığında sodyum borhidrürün hidroliz reaksiyonunun kinetik verileri incelendi, reaksiyonun aktivasyon enerjisi $27.581 \mathrm{kJmol}^{-1}$ olarak bulundu. $\mathrm{NaBH}_{4}$ hidrolizinde seria destekli Ni kompleksinin etkin bir katalizör olduğu görüldü.

Anahtar Kelimeler: Ni-kompleks, Sodyum borhidrür, Hidrojen üretimi. non-noble metal $(\mathrm{Pt}, \mathrm{Ru}, \mathrm{Pd} \mathrm{Co}, \mathrm{Ni}$, and $\mathrm{Cu}$ ) catalysts in many forms. ${ }^{4-11}$

To improve of the catalyst different studies have been tried. ${ }^{12-15}$ Between them a different support materials using is started to attract attention and be widely used. ${ }^{16}$, ${ }^{17}$ Typical catalyst supports include $\mathrm{TiO}_{2}{ }^{18-20}, \mathrm{Al}_{3} \mathrm{O}_{2}{ }^{21-23}$, $\mathrm{MgO}^{24}$, clays ${ }^{25}, \mathrm{SiO}_{2}{ }^{26,}{ }^{27}, \mathrm{CeO}_{2}{ }^{28}$, activated carbon ${ }^{29}$, etc... Though activated carbon is a good support material, the fabrication of activated carbon is expensive since it requires high-temperature values. Ceria support $\left(\mathrm{CeO}_{2}\right)$ is important material in hydrogen generation due to its storage performance, reducing activation energy and effect of oxygenation. ${ }^{30-32}$

Herein, the Ni complex (4-4'-methylenebis-(2,6-diethyl) aniline-3,5-di-tert-butylsalisylaldimine-Ni) ${ }^{33}$ was used to supported on ceria and the catalytic effects was 
investigated on sodium borohydride hydrolysis for hydrogen production. The catalytic studies were realized by different parameters at $30^{\circ} \mathrm{C}$. The aim of this study is to emphasize that ceria support can be used to increase the catalyst surface and to obtain the high hydrogen generation activity through hydrolysis of $\mathrm{NaBH}_{4}$. The experimental results show that the ceria supported $\mathrm{Ni}$ complex was an effective catalyst in hydrolysis of $\mathrm{NaBH}_{4}$. Moreover, ceria supported Ni complex catalyst was characterized with BET, FT-IR, XRD and SEM.

\section{MATERIALS AND METHODS}

\subsection{Materials}

All solvents: chloroform $\left(\mathrm{CHCl}_{3}\right)$, methyl alcohol $\left(\mathrm{CH}_{3} \mathrm{OH}\right)$, ethyl alcohol $\left(\mathrm{CH}_{3} \mathrm{CH}_{2} \mathrm{OH}\right)$, and the main chemicals: $\mathrm{NiCl}_{2} \cdot 6 \mathrm{H}_{2} \mathrm{O}, 4-4$ '-methylenebis-(2,6-diethyl) aniline, 3,5-ditertbutylsalisylaldehyde, and cerium oxide, $\mathrm{NaBH}_{4}, \mathrm{NaOH}$ were purchased from Merck and they were used without applying any purification.

Infrared spectrum was measured in the range of 4000-400 $\mathrm{cm}^{-1}$ on a PerkinElmer Spectrum 100 FTIR (ATR sampling accessory) spectrophotometer. With using Rigaku X-Ray diffractometer, the XRD patterns were determined. By using Brunauer-Emmett-Teller (BET) surface area measurement the important surface area parameters were identified. SEM results were determined with JEOL JSM 5800.

\subsection{Methods}

\subsubsection{Synthesis of ceria Supported-Ni complex}

By using mechanical mixing techniques ceria supported Ni complex catalyst was prepared. With varied amount of Ni complex was dissolved in ethanol $(10 \mathrm{~mL})$. Then $0.1 \mathrm{~g}$ ceria was added in this solution and stirred 72 $\mathrm{h}$ before filtration. In Figurel preparation of ceria supported Ni complex catalyst was shown.

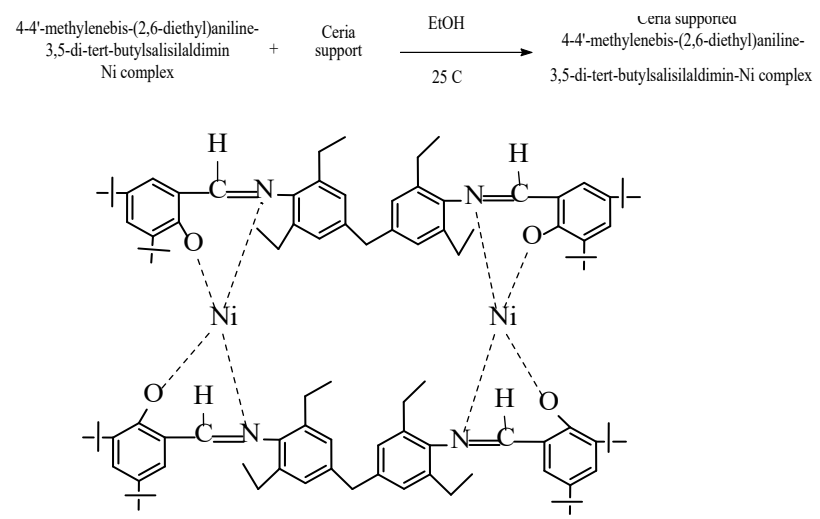

4-4'-methylenebis-(2,6-diethyl)aniline-3,5-di-tert-butylsalisilaldimine-Ni complex

Figure 1. Preparation of Ceria supported Ni complex
2.2.2. Catalytic sodium borohydride hydrolysis reaction

Catalytic hydrogen generation system occurred from $0.01 \mathrm{~g}$ catalyst that including $5 \% \mathrm{Ni}$ complex, with $10 \%$ $\mathrm{NaOH}$ in $10 \mathrm{~mL} 2.0 \% \mathrm{NaBH}_{4}$ solution at $30{ }^{\circ} \mathrm{C}$. The generated hydrogen amount was measured by using graduated cylinder. The proposed hydrogen volume is $560 \mathrm{~mL}$ for Equation 1.

\section{RESULTS AND DISCUSSION}

3.1. The influence of different parameters on the catalytic activity of ceria Supported-Ni complex in hydrogen generation

To research influence of $\mathrm{NaOH}$ concentration on the $\mathrm{H}_{2}$ generation, different $\mathrm{NaOH}$ concentrations from 0 to 10 $\%$ were tried with using ceria supported-Ni complex catalyst, while the concentration of $2 \% \mathrm{NaBH}_{4}$ at $30{ }^{\circ} \mathrm{C}$. The hydrogen generation rates increased as 8193.60; $8343.40 ; 11550.20 ; 14123.00 ; 16535.40 \mathrm{~mL} \mathrm{H}_{2} \mathrm{~g}_{\mathrm{cat}}{ }^{-1} \cdot \mathrm{min}^{-}$ ${ }^{1}$ in order of $0 \%, 5 \% 7 \%$, and $10 \% \mathrm{NaOH}$ and the reaction times decreased (Figure 2). In this study, $\mathrm{H}_{2}$ production rates increased with the increasing concentration of $\mathrm{NaOH}$.
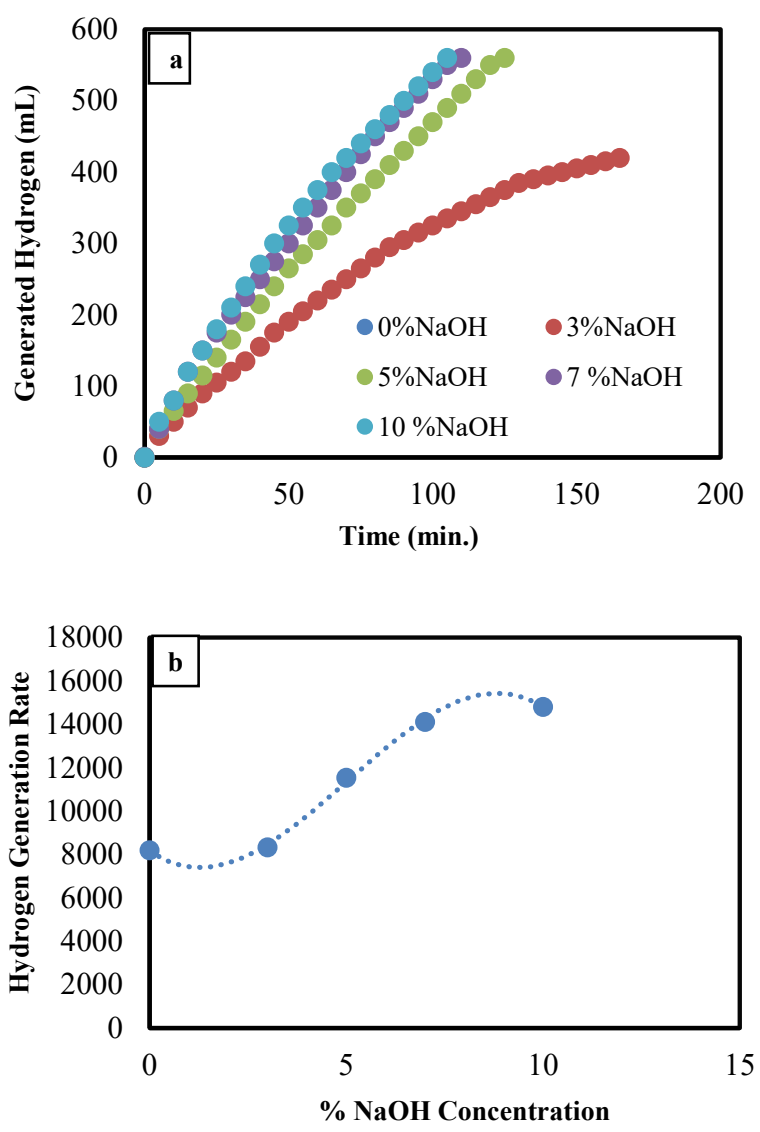

Figure 2. a) Influence of $\mathrm{NaOH}$ concentration, b) Graph of \% $\mathrm{NaOH}$ concentration to hydrogen generation rate (in $2 \%$ $\mathrm{NaBH}_{4}, 0.01 \mathrm{~g}$ catalyst at $30{ }^{\circ} \mathrm{C}$ ) 
To investigate the influence of $\mathrm{Ni}$ complex concentration in hydrogen generation, $5 \%, \% 10, \% 15, \% 20 \mathrm{Ni}$ complex concentrations were tried. For ceria supported $\mathrm{Ni}$ complex and tried in hydrogen generation reaction (Figure 3).

In Figure 3, it seen that with increasing $\mathrm{Ni}$ complex concentration hydrogen generation rates were started to decrease as $16535.40 ; 7540.40 ; 5560.53 ; 4758.15 \mathrm{~mL} \mathrm{H}_{2}$ $\mathrm{g}_{\text {cat }}{ }^{-1} \cdot \mathrm{min}^{-1}$ from $5 \%$ to $20 \% \mathrm{Ni}$ complex concentration. In this study, hydrogen generation rates decreased with the increasing concentration of $\mathrm{Ni}$ complex concentration in ceria supported $\mathrm{Ni}$ complex catalyst. The lower values from $5 \%$ was also investigated with $4 \% \mathrm{Ni}$ complex concentration, but surprisingly hydrogen generation rate was become to decrease to $16402.50 \mathrm{~mL} \mathrm{H} \mathrm{g}_{\mathrm{cat}}{ }^{-1} \mathrm{~min}^{-1}$ with generated $500 \mathrm{~mL}$ hydrogen. So that for this study \% $5 \mathrm{Ni}$ complex was preferred to use in ceria supported $\mathrm{Ni}$ complex catalys
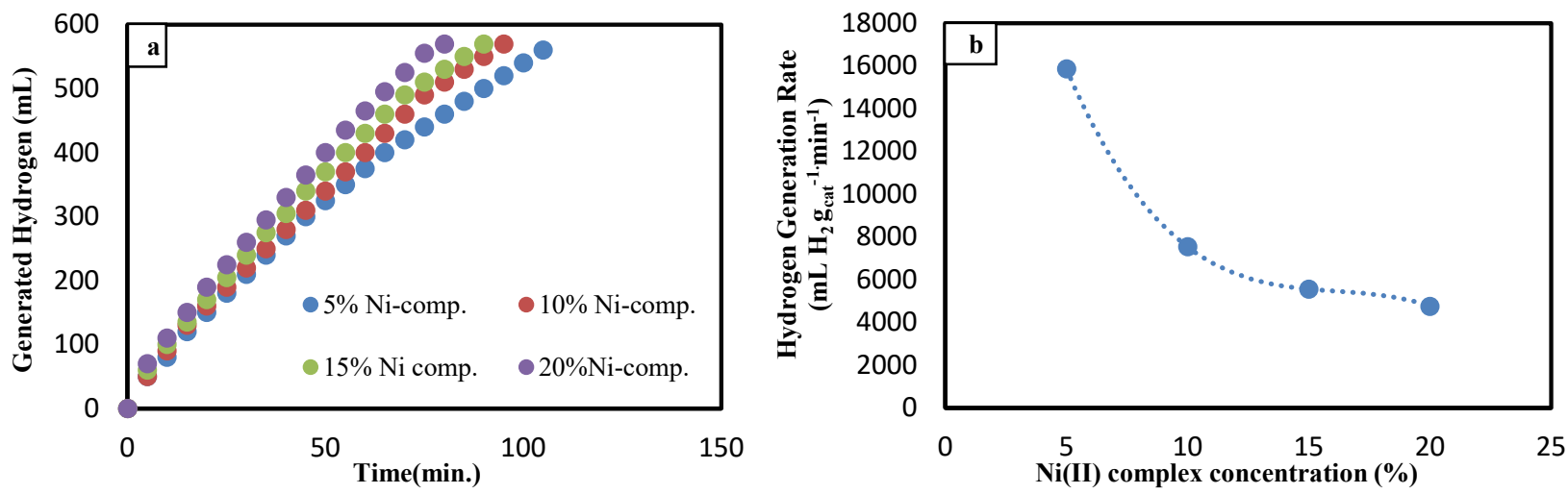

Figure 3. a) Influence of Ni complex concentration in hydrogen generation b) Graph of \% Ni concentration to hydrogen generation rate (in $2 \% \mathrm{NaBH}_{4}, 10 \% \mathrm{NaOH}, 0.01 \mathrm{~g}$ catalyst at $30{ }^{\circ} \mathrm{C}$ )

The effect of catalyst amount on hydrogen generation rate was investigated with several ceria supported $\mathrm{Ni}$ complex catalyst amounts as $0.005,0.01,0.025$, and 0.05 g including $5 \% \mathrm{Ni}$ complex in $2 \% \mathrm{NaBH}_{4}$ and $10 \%$ $\mathrm{NaOH}$ solution at $30{ }^{\circ} \mathrm{C}$ and the results are seen in Figure 4. As seen from Figure 4, there is an opposite ratio towards the $\mathrm{H}_{2}$ generation rates and amounts of catalyst as $20452.00 ; 16535.40 ; 6140.00 ; 3569.00 \mathrm{~mL} \mathrm{H}_{2} \mathrm{~g}_{\text {cat }}$ ${ }^{1} \mathrm{~min}^{-1}$. So that, $\mathrm{H}_{2}$ generation rates decreased with amounts of supported Ni complex increasing due to the catalyst surface saturation. However, $0.005 \mathrm{~g}$ catalyst has the best hydrogen generation rate $(20452.00)$, the predicted hydrogen volume is not provided $(490 \mathrm{~mL})$. So it was decided that the suitable catalyst amount is $0.01 \mathrm{~g}$ for this reaction $(560 \mathrm{~mL})$.
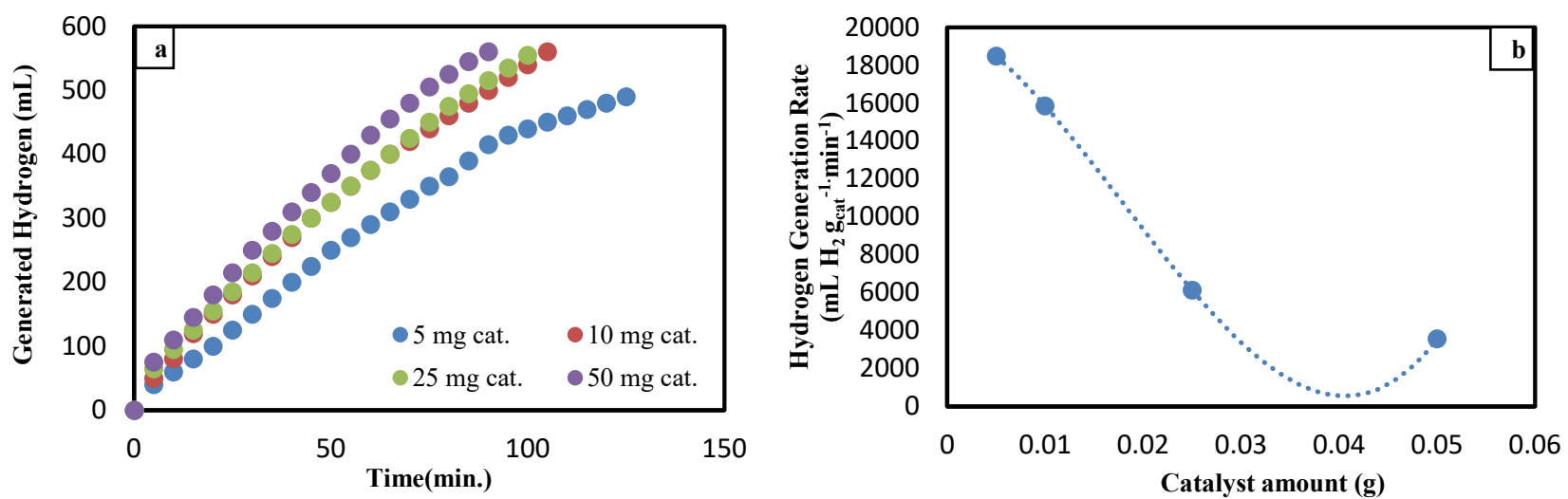

Figure 4. a) Influence of catalyst amount in hydrogen generation b) Graph of catalyst amount to hydrogen generation rate (in $2 \%$ $\mathrm{NaBH}_{4}, 10 \% \mathrm{NaOH}$ at $30{ }^{\circ} \mathrm{C}$ )

In order to check the sodium borohydride concentration on $\mathrm{H}_{2}$ generation rate, the different concentration of $\mathrm{NaBH}_{4}$ as $2 \%, 5 \%, 7 \%, 10 \%$ was tried in $10 \% \mathrm{NaOH}$ solution with $0.01 \mathrm{~g}$ ceria supported $\mathrm{Ni}$ complex at $30^{\circ} \mathrm{C}$. Ceria supported Ni complex was highly active catalyst, despite the improving $\mathrm{NaBH}_{4}$ percentage as shown in Figure 5. There was any important difference in $\mathrm{H}_{2}$ generation rates as $\mathrm{NaOH}$ concentration increased. It was shown that ceria supported $\mathrm{Ni}$ complex catalyzed $\mathrm{NaBH}_{4}$ hydrolysis was not depend on $\mathrm{NaBH}_{4}$ amount. 

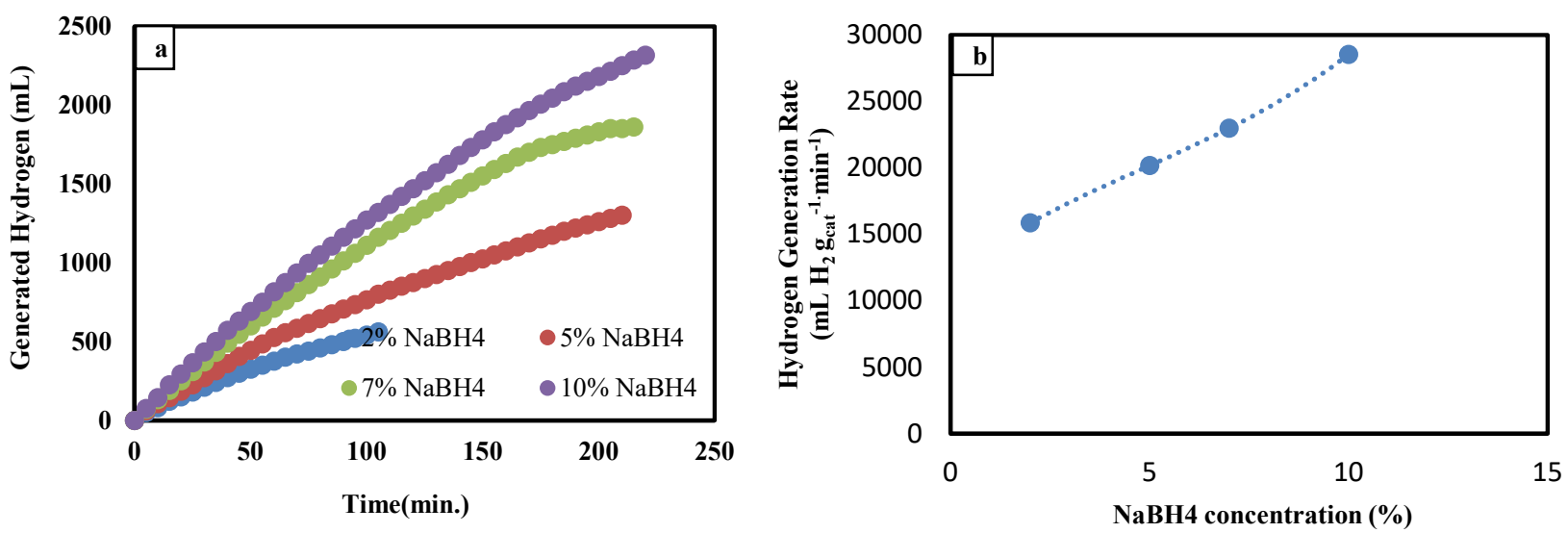

Figure 5. a) Influence of $\mathrm{NaBH}_{4}$ concentration in hydrogen generation b) Graph of $\% \mathrm{NaBH}_{4}$ concentration to hydrogen generation rate (in $10 \% \mathrm{NaOH}, 0.01 \mathrm{~g}$ catalyst at $30^{\circ} \mathrm{C}$ )

To research the effect of temperature on hydrogen generation rates, the studies were carried out at different temperatures as $20,30,40,50{ }^{\circ} \mathrm{C}$ with $2 \% \mathrm{NaBH}_{4}$ and $10 \% \mathrm{NaOH}$ solution and $0.01 \mathrm{~g}$ ceria supported-Ni complex catalyst. As shown in Figure 6 the hydrogen production rates increased with increasing reaction temperature as $8571.00 ; 16535.40 ; 20772.00 ; 23320.00$ $\mathrm{mL} \mathrm{H}_{2} \mathrm{~g}_{\mathrm{cat}}{ }^{-1} \cdot \mathrm{min}^{-1}$ respectively.
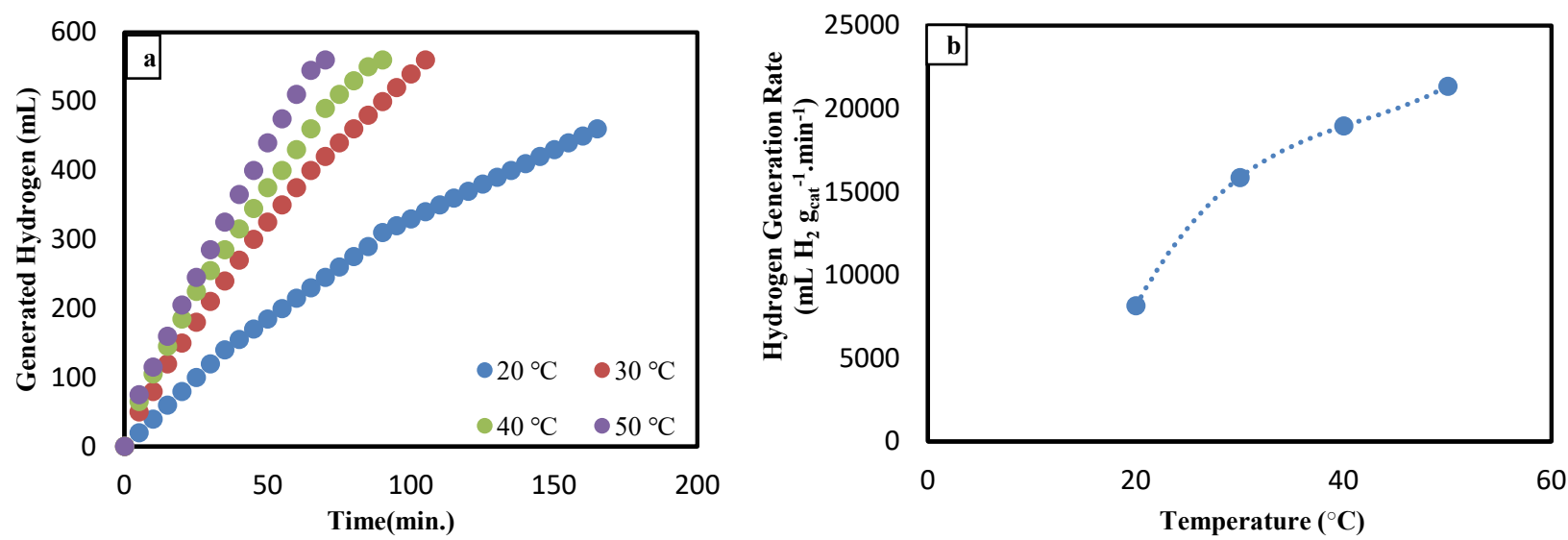

Figure 6. a) Influence of temperature on the hydrogen generation b) Graph of different temperatures to hydrogen generation rate (in $2 \% \mathrm{NaBH}_{4}, 10 \% \mathrm{NaOH}, 0.01 \mathrm{~g}$ catalyst)

\subsection{Kinetic studies of hydrogen generation}

Kinetic studies of ceria supported Ni complex catalyzed hydrogen generation reaction are described from $\mathrm{n}^{\text {th }}$ order reaction equation as;

$-\mathrm{r}_{\mathrm{NaBH} 4}=-\frac{\mathrm{dC}_{\mathrm{NaBH} 4}}{\mathrm{dt}}=\mathrm{k} \cdot \mathrm{C}_{\mathrm{NaBH} 4}^{\mathrm{n}}$

Separating and integrating, we obtain:

$-\int_{C_{N a B H 40}}^{C_{N a B H 4}} \frac{d C_{N a B H 4}}{C_{N a B H 4}^{n}}=k \int_{0}^{t} d t$

$\frac{1}{(n-1)}\left(\frac{1}{C_{N a B H 4}^{n-1}}-\frac{1}{C_{N a B H 40}^{n-1}}\right)=k t$
$\frac{1}{C_{N a B H 4}^{n-1}}=(n-1) k \cdot t+\frac{1}{C_{N a B H 40}^{n}}$

In Equation 5 the reaction rate order, $\mathrm{n}$ was recorded as 0.25 . From Figure 7 the rate constants, $\mathrm{k}$ was obtained. A linear curve was displayed in Figure 8 with Plotting Ln (k) versus to $(1 / \mathrm{T})$.

$$
\mathrm{k}=\mathrm{A} \cdot \exp (-\mathrm{Ea} / \mathrm{RT})
$$

The activation energy (Ea.) was recorded as $27.581 \mathrm{~kJ}$ $\mathrm{mol}^{-1}$. 


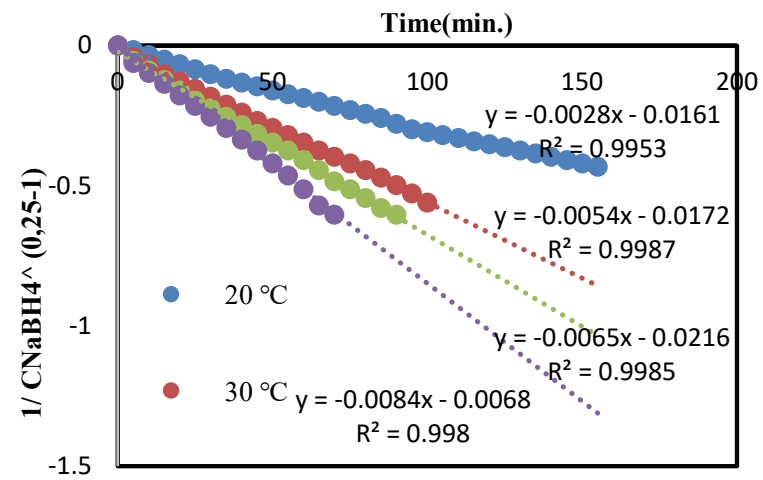

Figure 7. The linear regression based on $n^{\text {th }}$-order at $20{ }^{\circ} \mathrm{C}-50$ ${ }^{\circ} \mathrm{C}$

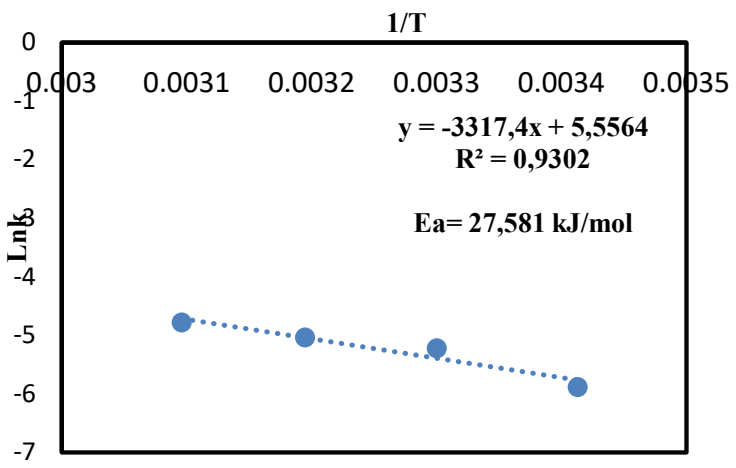

Figure 8. Arrhenius equation according to $\mathrm{n}^{\text {th }}$-order reaction

\subsection{Reusability of Ceria Supported Ni Complex Catalyst}

The stability of the ceria supported $\mathrm{Ni}$ complex catalyst was tried in the hydrolysis of $\mathrm{NaBH}_{4}$ by using in five times. Before reuse the catalyst washed with distilled water to take out the dirtiness on the catalyst. Ceria supported $\mathrm{Ni}$ complex exhibited excellent catalytic activity by providing $98 \%$ efficiency even in the 5 th cycle as shown in Figure 9.

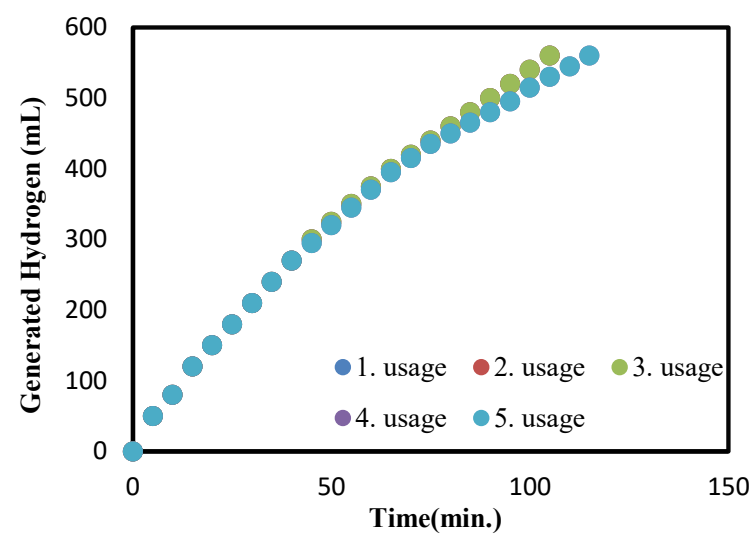

Figure 9. The reusability of ceria supported $\mathrm{Ni}$ complex catalyst by using five times in the hydrolysis of $\mathrm{NaBH}_{4}$
The experimental results indicate that the ceria supported $\mathrm{Ni}$ complex catalyst is highly stabile in hydrolysis of $\mathrm{NaBH}_{4}$.

\subsection{Characterization of ceria supported ni complex}

\subsubsection{FT-IR Spectrum}

The FT-IR measurement was performed to investigate with compare the ceria supported $\mathrm{Ni}$ complex and $\mathrm{Ni}$ complex [1]. In Table 1 the band that occurred at 2896 $\mathrm{cm}^{-1}$ are due to the free $-\mathrm{OH}$ groups or intramolecular $\mathrm{OH}^{\cdots} \mathrm{N}$ which seen both ceria supported $\mathrm{Ni}$ complex and $\mathrm{Ni}$ complex. Both ceria supported $\mathrm{Ni}$ complex and $\mathrm{Ni}$ complex the band that occurred at $2745-2976 \mathrm{~cm}^{-1}$ was corresponding to methyl group. At $1602-1619 \mathrm{~cm}^{-1}$ band for $\mathrm{Ni}$ complex, for azomethine $(\mathrm{C}=\mathrm{N})$ group was changed as $1607-1623 \mathrm{~cm}^{-1}$ in ceria supported $\mathrm{Ni}$ complex. For phenolic $-\mathrm{C}=\mathrm{O}$ - the bands were occurred at $1692-1733 \mathrm{~cm}^{-1}$ and $1689-1748 \mathrm{~cm}^{-1}$ as ceria supported Ni complex and pure Ni complex respectively.

$5 \% \mathrm{Ni}$ complex containing ceria supported Ni complex catalyst has the stronger bands in $512 \mathrm{~cm}^{-1}$ that verified the formation of complex on the oxygen atom to metal atom (M-O) and at $421 \mathrm{~cm}^{-1}$ corresponded to vibrations of nitrogen atom and metal atom (M-N), and the same bands are present on pure $\mathrm{Ni}$ complex.

Table 1. The results of FT-IR spectrum for Ceria supported Ni complex

\begin{tabular}{|c|c|c|c|c|c|c|}
\hline Complex & $\begin{array}{l}\frac{\mathrm{cm}^{-1}}{} \overline{\bar{v}-\mathrm{O}-\mathrm{H}} \\
\text { (intra } \\
\text { molec } \\
\text { ular) }\end{array}$ & $\begin{array}{c}\delta \\
-\mathrm{CH}_{3}\end{array}$ & $\begin{array}{c}\bar{v} \\
-\mathrm{C}=\mathrm{N}-\end{array}$ & $\begin{array}{c}\bar{v} \\
-\mathrm{C}=\mathrm{O}-\end{array}$ & $\begin{array}{c}\bar{v}- \\
\mathrm{M}-\mathrm{N}\end{array}$ & $\begin{array}{c}\bar{v}- \\
\mathrm{M}-\mathrm{O}\end{array}$ \\
\hline Ni complex & 2896 & $\begin{array}{c}2745 \\
- \\
2976 \\
\end{array}$ & $\begin{array}{c}1602 \\
- \\
1619 \\
\end{array}$ & $\begin{array}{c}1689 \\
- \\
1748 \\
\end{array}$ & 421 & 512 \\
\hline $\begin{array}{l}\text { Ceria } \\
\text { supported } \\
\text { Ni complex }\end{array}$ & 2896 & $\begin{array}{c}2753 \\
- \\
2977\end{array}$ & $\begin{array}{c}1607 \\
- \\
1623\end{array}$ & $\begin{array}{c}1692 \\
- \\
1733\end{array}$ & 421 & 512 \\
\hline
\end{tabular}

\subsubsection{X-Ray Diffractograms (XRD)}

In Figure 10, the XRD patterns of ceria supported-Ni complex were displayed.

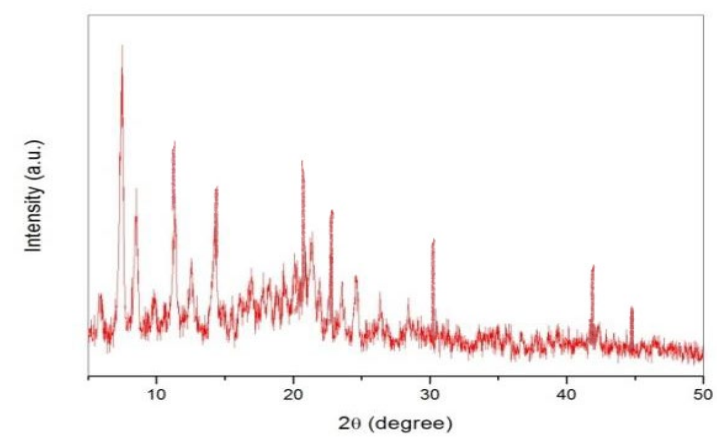

Figure 10. XRD results of Ceria supported Ni complex 
It was understood that the catalyst has a completely crystal structure. For ceria supported-Ni complex, the major diffraction peaks were observed at $8.62 ; 9.69$; $12.77 ; 14.92 ; 20,86 ; 23.41 ; 30.79 ; 43.06$ and 44.91 respectively.

\subsubsection{Brunauer-Emmett-Teller surface area analysis (BET)}

Ceria supported Ni complex has a big surface area and that provide to increase the catalytic activity. For pure $\mathrm{Ni}$ (II) complex the surface area was recorded as 33.284 $\mathrm{m}^{2} \mathrm{~g}^{-1}$ and for ceria supported Ni complex, it was 64.377 $\mathrm{m}^{2} \mathrm{~g}^{-1}$ as indicated in Table 2. For ceria supported $\mathrm{Ni}$ complex the pore volumes increased almost more than 2 times than pure Ni complex.

Table 2. BET analysis results of catalyst

\begin{tabular}{|c|c|c|c|}
\hline Catalyst & $\begin{array}{c}\text { Average } \\
\text { Pore Ratio } \\
(\mathbf{~ n m})\end{array}$ & $\begin{array}{c}\text { Pore } \\
\text { Volume } \\
\left(\mathbf{~ c m}^{\mathbf{3}} \mathbf{g}^{-1}\right)\end{array}$ & $\begin{array}{c}\text { S BET } \\
\left(\mathbf{~ m}^{\mathbf{2}} \mathbf{g}^{-1}\right)\end{array}$ \\
\hline Ni Complex & 10.569 & 0.132 & 33.284 \\
\hline $\begin{array}{c}\text { Ceria } \\
\text { supported Ni } \\
\text { Complex }\end{array}$ & 14.245 & 0.235 & 64.377 \\
\hline
\end{tabular}

\subsubsection{Scanning electron microscopy analysis (SEM)}

For ceria supported Ni complex the SEM images were displayed in Figure 11. It was clearly seen that ceria supported $\mathrm{Ni}$ complex catalyst display completely homogeneous structure. According to SEM results the surface of ceria supported Ni complex catalyst was fully coated by Ni complex as shown in Figure 11.
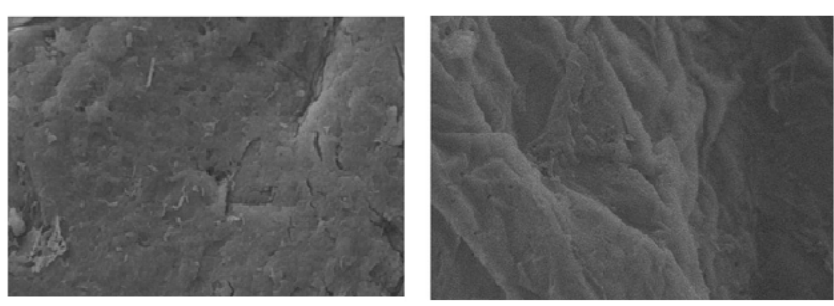

Figure 11. SEM images of Ceria supported Ni complex

generation. ceria supported Ni complex catalyst catalysts was characterized with using the SEM, BET, XRD and FTIR. The highest hydrogen generation rate was $16535.40 \mathrm{~mL} \mathrm{H}_{2} \mathrm{~g}_{\text {cat }}{ }^{-1} \cdot \mathrm{min}^{-1}$ and $23320.00 \mathrm{~mL} \mathrm{H}_{2} \mathrm{~g}_{\text {cat }}{ }^{-}$ ${ }^{1} . \mathrm{min}^{-1}$ at $30{ }^{\circ} \mathrm{C}$ and $50{ }^{\circ} \mathrm{C}$ respectively by using $0.01 \mathrm{~g}$ ceria supported-Ni complex catalyst. In summary, ceria supported Ni complex catalyst exhibited greater activity in hydrogen generation. The activation energy (Ea.) was recorded as $27.581 \mathrm{~kJ} / \mathrm{mol}$. The reusability tests showed the catalyst retained $98 \%$ of its activities after fifth cycles. The hydrogen generation performance the comparison of ceria supported Ni complex and various $\mathrm{Ni}$ based catalysts in $\mathrm{NaBH}_{4}$ hydrolysis reaction is shown in Table 3. Consequently, the prepared ceria supported Ni complex catalyst can be used as highly active, practical and low-cost materials for hydrogen generation in sodium borohydride hydrolysis.

Table 3. The hydrogen generation performance comparison of ceria supported Ni complex catalyst and various $\mathrm{Ni}$ catalysts in $\mathrm{NaBH}_{4}$ hydrolysis reaction

\begin{tabular}{|c|c|c|}
\hline Catalyst & $\begin{array}{c}\text { Hydrogen } \\
\text { Generation Rate } \\
\left(\mathrm{mL} \mathrm{H} \mathbf{H}_{2} \mathrm{gat}^{-1} \cdot \mathrm{min}^{-1}\right)\end{array}$ & References \\
\hline Ceria/ Ni-complex & 16535.40 & In This Study \\
\hline $\mathrm{Ni}-\mathrm{Co} / \mathrm{r}-\mathrm{GO}$ & 1280.00 & 34 \\
\hline $\mathrm{CoB} / \mathrm{Ni}$-foam & 1930.00 & 35 \\
\hline $\begin{array}{c}\mathrm{Co}-\mathrm{Ni}-\mathrm{Mo}-\mathrm{P} / \mathrm{g}- \\
\mathrm{Al} 2 \mathrm{O} 3\end{array}$ & 10125.00 & 36 \\
\hline $\mathrm{Ni}(\mathrm{II})$-complex & 2240.00 & 37 \\
\hline $\mathrm{NiCo}_{2} \mathrm{O}_{4}$ & 1000.00 & 38 \\
\hline
\end{tabular}

\section{CONCLUSIONS}

In present study, ceria supported $\mathrm{Ni}$ complex was prepared for $\mathrm{NaBH}_{4}$ hydrolysis reaction to hydrogen generation. ceria supported Ni complex catalyst catalysts was characterized with using the SEM, BET, XRD and FTIR. The highest hydrogen generation rate was $16535.40 \mathrm{~mL} \mathrm{H}_{2} \mathrm{~g}_{\mathrm{cat}}{ }^{-1}$. $\mathrm{min}^{-1}$ and $23320.00 \mathrm{~mL} \mathrm{H}_{2} \mathrm{gcat}^{-}$ ${ }^{1} . \mathrm{min}^{-1}$ at $30{ }^{\circ} \mathrm{C}$ and $50{ }^{\circ} \mathrm{C}$ respectively by using $0.01 \mathrm{~g}$ ceria supported-Ni complex catalyst. In summary, ceria supported Ni complex catalyst exhibited greater activity in hydrogen generation. The activation energy (Ea.) was recorded as $27.581 \mathrm{~kJ} / \mathrm{mol}$. The reusability tests showed the catalyst retained $98 \%$ of its activities after fifth cycles. The hydrogen generation performance the comparison of ceria supported Ni complex and various $\mathrm{Ni}$ based catalysts in $\mathrm{NaBH}_{4}$ hydrolysis reaction is shown in Table 3. Consequently, the prepared ceria supported $\mathrm{Ni}$ complex catalyst can be used as highly active, practical and low-cost materials for hydrogen generation in sodium borohydride hydrolysis.

\section{Conflict of interests}

Authors declare that there is no a conflict of interest with any person, institute, company, etc. 


\section{REFERENCES}

1. Dillon, A.C.; Jones, K.M.; Bekkedahl, T.A.; Kiang, C.H.; Bethune, D.S.; Heben, M.J. Nature. 1997, 386, 377-379.

2. Sahiner, N, Sengel, SB. Fuel Process Technol. 2017 , $158,1-8$.

3. Kaufman, C.M.; Sen, B. J. Chem. Soc. Dalton Trans. 1985, 307-313.

4. Schlapbach, L.; Zuttel, A. Nature. 2001, 414, 353-8.

5. Sahiner, N.; Yasar, A.O.; Aktas, N. J. Ind. Eng. Chem. 2015, 23, 100-8.

6. Kojima, Y.; Kawai, Y.; Nakanishi, H.; Matsumoto, S. J. Power Sources. 2004, 135, 36-41.

7. Kilinc, D.; Saka, C.; Sahin, O. J. Power Sources. 2012, 217, 256-261.

8. Ceyhan, A.A.; Edebali, S.; Fangaj, E. Int. J. Hydrogen Energ. 2020, 45, 34761-34772.

9. İzgi, MS.; Baytar, O.; Şahin, O.; Horoz, S. Dig. J. Nanomater. Bios. 2019, 14, 1005-1012.

10. Kilinc, D.; Sahin O.; Int. J. Hydrogen Energ. 2018, 43, 10717-10727.

11. Kilinc, D. Energ Sources Part A. 2018, 40, 873-885.

12. Iwasa, N.; Masuda, S.; Ogawa, N.; Takezawa, N. Appl. Catal. A-Gen. 1995, 125, 145-157.

13. Iwasa, N.; Mayanagi, T.; Nomura, W.; Arai, M.; Takezawa, N. Appl. Catal. A-Gen. 2003, 248,153-160.

14. Glisenti, A.; Galenda, A.; Natile, M.M. Appl. Catal. A- Gen. 2013, 453, 102-112.

15. Krajcí, M.; Tsai, A.P.; Hafner, J. J. Catal. 2015, 330, 6-18.

16. Hernández, R.P.; Martínez, A.G. ; Mayoral, A.; Deepak, F.L.; García, M.E.F.; Galicia, G.M.; Miki, M.; Yacamán, M. J. Adv. Mater. Res. 2010, 132, 205-219.

17. Friedrich, M.; Teschner, D.; Gericke, A.K.; Armbrüster, M. J. Phys. Chem. C. 2012, 116, 1493014935.

18. Hannauer, J; Demirci, UB; Pastor, G; et al. Energ. Environ. Sci. 2010, 3, 1796.

19. Larichev, YV; Netskina, OV; Komova, OV; et al. Int. J. Hydrogen Energ. 2010, 35, 6501-7.
20. Kilinc D.; Sahin O.; Int. J. Hydrogen Energ. 2019, 44, 18858-18865.

21. Xu, D; Zhao, L; Dai, P; et al. J. Nat. Gas Chem. 2012, 21, 488-94.

22. Wu C; Williams PT. Appl. Catal. B-Environ. 2009, $87,152-61$

23. Kilinc, D.; Sahin, O.; Int. J. Hydrogen Energ. 2019 , 44, 28391-28401.

24. Crisafulli, C.; Scir, S; Salanitri, M; et al. Int. J. Hydrogen Energ. 2011, 36, 3817-26.

25. Tian, H; Guo, Q; Xu D. J. Power Sources. 2010, 195, 2136-42.

26. Yan, K; Li, Y; Zhang, X; et al. Int. J. Hydrogen Energ. 2015, 40, 16137-16146.

27. Kilinc, D. J. Baun Inst. Sci. Technol. 2018, 20, 296310 .

28. Greluk, M.; Rotko, M.; Surdacka, ST. Renew. Energ. 2020, 155, 378-395.

29. Crisafulli, C; Scire, S; Zito, R; et al. Catal. Lett. 2012 , $142,882-8$

30. Levalley, T.L.; Richard, A.R.; Fan, M. Int. J. Hydrogen Energ. 2014, 39, 16983-17000.

31. Ciambelli, P.; Palma, V.; Ruggiero, A. Appl. Catal. B-Environ. 2010, 96, 18-27.

32. Piedras, A.C.; Zamora, R. M.R.; Vázquez, B.C.A.; Martínez, A.G.; Galicia, G.M.; Anzures, F.M.; Hernández, R.P. Catal. Today. 2020, Article in Press.

33. Sahin, O.; Kilinc, D.; Saka, C. J. Energy Institut. 2016, 89, 617-626.

34. Chou, C.C.; Hsieh, C.H.; Chen, B.H. Energy. 2015, 50, 1973-1982.

35. Guoa, S.; Wua, Q.; Sun, J.; Chen, T.; Feng, M.; Wang, Q.; Wang, Z.; Zhao, B.; Ding, D. Int. J. Hydrogen Energ. 2017, 42, 21063-21072.

36. Wang, L.; Li, Z.; Zhang, P.; Wang, G.; Xie G. Int. J. Hydrogen Energ. 2016, 41, 1468-1476.

37. Kilinc, D.; Sahin, O.; Saka, C. Int. J. Hydrogen Energ. 2017, 42, 20625-20637.

38. Jadhav, A.R.; Bandal, H.A.; Kim H. Mater. Lett. 2017, 198, 50-53. 